\title{
Manajemen Perencanaan Pembelajaran Aktif di Lembaga Kursus Bahasa Arab Al-Azhar Pare Kediri
}

\author{
Muhammad Kholilur Rosyid \\ Universitas Islam Negeri Maulana Malik Ibrahim Malang \\ kholilurrosyid17@gmail.com
}

\section{Moch. Sulthoni Faizin}

Universitas Islam Negeri Maulana Malik Ibrahim Malang redprison09@gmail.com

\section{Nazahah Ulin Nuha}

Universitas Islam Negeri Maulana Malik Ibrahim Malang insyaallahberkah424@gmail.com

\section{Zakiyah Arifa}

arifazakiyah@uin-malang.ac.id

Universitas Islam Negeri Maulana Malik Ibrahim Malang

DOI: http://dx.doi.org/10.18326/lisania.v3i1.1-20

\begin{abstract}
Al-Azhar is one of the famous foreign language courses in Pare Kediri. This research is conducted because Al-Azhar Course Institute has interesting programs, and some teaching staff are native Arabs (Yemen), and use fun methods that make it easier for students to understand and Arabic quickly. This study aims to describe the planning and design of learning in Al-Azhar course institutions. This study uses qualitative research with descriptive methods. Data collection is done by observation, interview and documentation. Data is obtained from informants who are instructors at the Al-Azhar Course Institute. Data analysis in this study consists of 3 stages, namely: Data Condensation, Data Display, and Conclusion Drawing / Verification. The results obtained in this study are: First, the planning carried out by the Al-Azhar course institution is a type of project planning, and top-down planning. Second, the design of learning that is carried out is initiated by placement test, then determines the material that is in accordance with students' abilities, and finally evaluates.
\end{abstract}

Keywords: Planning, Design, Arabic Language Course

\begin{abstract}
Abstrak
Al-Azhar adalah salah satu lembaga kursus bahasa asing yang terkenal di Pare Kediri. Penelitian ini dilakukan karena Lembaga Kursus Al-Azhar mempunyai program-program yang menarik, serta sebagian tenaga pengajar merupakan orang Arab asli (Yaman), dan menggunakan metode yang menyenangkan sehingga memudahkan para pelajar memahami dan mengerti
\end{abstract}


Bahasa Arab dengan cepat. Penelitian ini bertujuan untuk mendeskripsikan perencanaan dan desain pembelajaran di lembaga kursus Al-Azhar. Penelitian ini menggunakan penelitian kualitatif dengan metode deskriptif. Pengumpulan data dilakukan dengan observasi, wawacara dan dokumentasi. Data diperoleh dari informan yang merupakan pengajar di Lembaga kursus Al-Azhar. Analisis data dalam penelitian ini terdiri dari 3 tahap yaitu: Data Condensation, Data Display, dan Conclusion Drawing/Verification. Hasil yang di peroleh dalam penelitian ini adalah: Pertama, perencanaan yang dilakukan oleh lembaga kursus Al-Azhar merupakan jenis perencanaan proyek, dan perencanaan top-down. Kedua, desain pembelajaran yang dilakukan adalah diawali dengan placement test, kemudian menentukan materi yang sesuai dengan kemampuan siswa, dan terakhir evaluasi.

Kata Kunci: Perencanaan, Desain, Kursus Bahasa Arab

\section{Pendahuluan}

Pada umumnya manajemen dapat diartikan sebagai seni atau proses untuk membuat suatu aktifitas organisasi baik usaha sendiri maupun kelompok, guna mencapai tujuan bersama (Rohman dan Amri, 2015: 2). Setiap proses Pasti memiliki unsur-unsur begitu pula dengan manajemen, memiliki beberapa unsur yaitu persiapan (preparation), penyampaian (presentation), latihan (practice) dan penampilan hasil (performance) (Meier, 2002: 103). Manajemen juga memiliki 4 fungsi pokok yaitu perencanaan, pengorganisasian, pengawasan dan evaluasi (penilaian).

Fungsi pertama manajemen adalah perencanaan yang dapat didefinisikan sebagai suatu proses petunjuk suatu aktifitas untuk mencapai suatu tujuan dari segi persiapan dan prosedur. Maka setiap program harus diawali dengan perencanaan atau persiapan guna mencapai tujuan sesuai harapan begitu pula dalam manajemen pembelajaran. Agar pelaksanaan pembelajaran berjalan dengan baik, maka dibutuhkan perencanaan yang baik pula. Sehingga pembelajaran yang dilaksanakan bisa berjalan dengan efektif dan tepat sasaran sesuai tujuan pembelajaran yang sudah ditetapkan.

Keberhasilan lembaga kursus Al-Azhar dalam merencanakan, mengelola dan mengembangkan lembaganya menjadi lembaga yang besar dan menjadi lembaga kursus Bahasa Arab yang terkenal di Pare Kediri merupakan hal yang sangat menarik untuk diteliti. Lembaga kursus bahasa 
Arab Al-Azhar adalah salah satu kursus yang memiliki tujuan meningkatkan kemampuan dan keterampilan berbahasa Arab hingga mampu berkomunikasi pasif maupun aktif. Keterampilan tersebut meliputi keterampilan mendengar, keterampilan berbicara, keterampilan membaca dan keterampilan menulis.

Kursus Bahasa Arab Al-Azhar memiliki banyak program pembelajaran sesuai kebutuhan dan minat seperti, program timur tengah, program mahir baca kitab kuning, program dasar baca kitab, dan program lancar ngomong Arab. Di samping itu, mereka juga menggunakan metode pembelajaran yang menarik dan mempermudah siswa dalam belajar seperti metode al-Miftah dari Sidogiri. Dengan adanya tujuan maka kursus bahasa Arab Al-Azhar telah menyiapkan rancangan atau perencanaan untuk mencapainya.

Pada penelitian ini lebih membahas manajemen perencanaan program pembelajaran lancar ngomong Arab, karena program ini lebih menonjol dibanding dengan program-program yang lainnya. Program ini disusun khusus untuk siswa yang bertujuan agar bisa dan lancar berbicara bahasa Arab aktif maupun pasif. Strategi pembelajaran pada program ini menggunakan strategi langsung yang bertujuan agar siswa dapat berbicara dengan lancar seperti menceritakan apa yang dilihat.

Berdasarkan uraian diatas, maka penelitian dapat difokuskan dengan dua pembahasan, yaitu; 1) Bagaimana manajemen perencanaan dalam Kursus Bahasa Arab Al-Azhar? 2) bagaimana perancangan pembelajaran di Kursus Bahasa Arab Al-Azhar?.

\section{Metode Penelitian}

Metode penelitian adalah salah satu bagian terpenting dalam sebuah penelitian. Dalam bagian ini ada beberapa pokok yang akan dipaparkan meliputi, jenis penelitian, sumber data, teknik pengumpulan data dan teknik analisis data.

\section{Jenis Penelitian}

Metode penelitian yang digunakan pada penelitian ini adalah kualitatif deskriptif. Peneliti menggunakan penelitian kualitatif karena 
bertujuan untuk memperoleh informasi atau menggambaran suatu hal yang diteliti dan tidak bisa didapatkan dengan cara pengukuran atau statistika, misalnya: ide, persepsi, pendapat dan lain sebagainya (Sulistyo, 2006: 78). Penelitian ini juga bersifat deskriptif yaitu sebagai alat atau metode pemecah masalah yang sedang diteliti dengan mendeskripsikan atau menggambarkan objek penelitian (Soejono dan Abdurrahman, 1999: 23) yang bertujuan untuk membantu pembaca mengetahui apa yang terjadi sekitar penelitian, seperti lingkungan, pandangan, keadaan, aktivitas dan latar belakang pengamatan (Emzir, 2017: 174).

Dalam hal ini, peneliti mendeskripsikan Al-Azhar dari segi manajemen perencanaan. Membahas tentang perencanaan-perencanaan pembelajaran di Al-Azhar mengenai macam paket belajar, metode, strategi dan sarana prasarana sehingga dapat melakukan kegiatan pembelajaran sesuai dengan rencana untuk mencapai target yang dituju (Rahmawati, Journal of Arabic Studies, 3 (1), 2018: 52-60). Adapun data primer dalam penelitian ini adalah tenaga pengajar di lembaga kursus Al-Azhar, dan data sekundernya adalah buku panduan dan brosur-brosur di lembaga kursus Al-Azhar.

\section{Teknik Pengumpulan Data}

Peneliti menggunakan teknik pengumpulan data dengan wawancara, observasi dan dokumentasi di Al-Azhar. Yaitu melakukan percakapan antar dua pihak dengan tujuan untuk memperoleh informasi (Moelong, 2014: 186). Dalam penelitian ini data primer diperoleh dari pengajar dengan melakukan wawancara dengan ustadz Anas seputar pembelajaran di Al-azhar. Peneliti juga melakukan observasi dan dokumentasi guna mendukung dan melengkapi data dari hasil wawancara (Harsono, 2008: 164) yaitu melalui pengamatan secara cermat dan nyata (Ainin, 2016: 121). Pada observasi kami berkeliling melihat dan mengamati keadaan dan situasi di Al-azhar. Dimana peneliti melihat kondisi kelas, yaitu berupa bagian rumah yang dialih fungsikan sebagai kelas-kelas, misal pada ruang bagian tengah, belakang dan depan. Terakhir, adalah dokumentasi dengan cara mengumpulkan arsip atau tulisan yang berhubungan dengan data 
yang dibutuhkan guna melengkapi data dari hasil wawancara dan observasi, seperti buku pedoman, selebaran, dan brosur (Arikunto, 2010: 274). Dalam hal ini kami mendapatkan brosur atau selebaran dari program-program yang ditawarkan kepada calon pelajar.

\section{Teknik Analisis Data}

Setelah data yang dibutuhkan terkumpul, maka dilakukan analisis data dengan teknik kualitatif deskriptif. Menurut Miles, Huberman dan Saldana (2014) pada penelitian kualitatif terdapat tiga proses atau alur kegiatan, yaitu Data Condensation, Data Display, dan Conclusion Drawing/ Verification (Miles dkk, 2014: 31-33).

Data Condensation yaitu proses memilih, menyederhanakan, mengabstrakkan atau mentransformasi data. Pada penelitian ini kami mencatat terlebih dahulu hasil wawancara, observasi dan dokumentasi dalam bentuk ringkasan, kemudian kita memilah dan memilih data yang sesuai dengan apa yang kita butuhkan. Sedangkan data Display yaitu penyajian data yang membantu dalam memahami tentang apa yang terjadi dan memberi hubungan agar memungkinkan untuk adanya kesimpulan. Setelah memilih dan memilah data kami melakukan klasifikasi data dan mengolah data sesuai dengan apa yang akan kita teliti yaitu perencanaan dan desain pembelajaran. Adapun Conclusion Drawing/Verification yaitu penarikan kesimpulan yang berguna untuk memperjelas penalaran atau hasil penelitian. Pada tahap ini peneliti memaparkan dan melaporkan hasil penelitian dan penemuan yang berbeda dengan peneliti sebelumnya secara lengkap dan jelas terkait perencanaan dan desain pembelajaran.

\section{Manajemen Pembelajaran}

Arikunto mengutip dari Kamus Umum Bahasa Indonesia mengatakan bahwa manajemen yaitu kegiatan pengurusan atau penyelenggaraan agar sesuatu yang dikelola dapat berjalan dengan efektif, efisien dan lancar (Arikunto, 1996: 6-7). Sedangkan menurut ahli lain, manajemen adalah kemampuan untuk melakukan atau melaksanakan kegiatan baik secara individu maupun bersama orang lain untuk mewujudkan tujuan organisasi 
(Sudjana, 2000: 17). Maka manajemen dapat disimpulkan sebagai proses kegiatan yang pelaksanaannya membutuhkan sumber daya seperti manusia atau material secara efektif dan efisiesn untuk mencapai tujuan yang telah ditentukan (Putra, 2018: 136).

Dalam proses belajar mengajar, manajemen merupakan satuan pendidikan yang sangat penting dalam sukses dan tidaknya proses belajar mengajar tersebut. Manajemen pembelajaran mempunyai peranan penting dalam setiap satuan komponen pendidikan, karena akan menentukan kualitas para lulusan. Pembelajaran adalah suatu kegiatan atau proses yang sistemik dan sistematis, yang bersifat komunikatif dan interaktif antara pendidik dengan peserta didik, dan sumber belajar, serta lingkungan agar terciptanya suatu kondisi yang memungkinkan terwujudnya proses belajar peserta didik, di luar kelas maupun di dalam, dihadiri guru atau tidak, serta untuk menguasai suatu kompetensi yang sudah ditetapkan (Arifin, 2009: 3).

Dalam arti luas, manajemen pembelajaran merupakan kegiatan mengelola bagaimana membelajarkan pelajar dengan kegiatan yang diawali dari perencanaan, pengorganisasian, pengendalian, dan penilaian. Adapun dalam arti yang lebih sempit adalah suatu kegiatan yang dikelola oleh pendidik selama proses interaksinya dengan para pelajar dalam proses pembelajaran. Sedangkan definisi lain manajemen pembelajaran berarti kegiatan kerjasama untuk menggapai tujuan dari proses belajar mengajar yang dapat dilihat dari kerangka berpikir dari suatu sistem. Manajemen pembelajaran juga memiliki pengertian suatu proses guna mencapai tujuan dari proses belajar-mengajar yang mana dimulai dari perencanaan, pengarahan, pengawasan dan evaluasi (penilaian) (Suryobroto, 2006: 16).

Berdasarkan definisi-definisi di atas dapat disimpulkan bahwa manajemen pembelajaran adalah suatu kegiatan pengelolaan pembelajaran yang meliputi perencanaan, pengorganisasian, pengendalian serta evaluasi guna mencapai tujuan pembelajaran yang telah ditentukan oleh pendidik (guru). 


\section{Perencanaan}

Perencanaan adalah kegiatan yang harus dilakukan sebelum melaksanakan sesuatu dalam waktu tertentu untuk mecapai tujuan yang diharapkan. Perencanaan juga bisa disebut sebagai proses persiapan kegiaan-kegiatan yang sistematis yang digunakan untuk mencapai tujuan yang diinginkan atau sasaran tertentu (Usman, 2006: 48). Perencanaan meiliki peran sangat penting untuk melaksanakan kegiatan pembelajaran karena suatu kegiatan akan lebih optimal jika menyiapkan perencanaan terlebih dahulu (Ernawati, Arabiyat, 5 (1), 2018: 15-37). Sedangkan perencanaan pembelajaran adalah suatu usaha atau upaya untuk mencapai tujuan yang melibatkan diri sendiri dan orang lain dari segi pembelajaran seperti peningkatan minat belajar siswa dan keberhasilan belajar.

Perencanaan dalam penelitian ini berperan sebagai sistem, yaitu perencanaan berguna sebagai prosedur-prosedur dan sumber-sumber untuk menggerakan suatu kegiatan dalam hal ini yang dimaksud adalah pembelajaran (Suryapermana, Tarbawi, 3 (2), 2017: 184). Maka dengan adanya perencanaan, suatu kegiatan akan berjalan teratur, efektif dan bertujuan (Talibo, Iqra', 11 (2), 2013: 18 ).

Dalam perencanaan terdapat ruang lingkup yang dipengaruhi oleh beberapa faktor seperti perencannan dari dimensi waktu, perancanaan dari dimensi tingkatan teknik perencanaan dan perencanaan dari dimensi jenis (Usman, 2006: 48).

Perencanaan dari dimensi waktu. 1) Perencanaan jangka panjang (long term planning) yaitu jangka waktu yang mencapai 10 tahun keatas. Dalam jangka waktu ini belum ditentukan sasaran secara kuantitatif. Namun, pencapaian yang diinginkan sudah ditunjukkan. Misal: Propenas. 2) Perencanaan jangka menengah (medium term planning) yaitu jangka waktu perencanaan yang mencapai 3 sampai 8 tahun. Pada umumnya di Indonesia 5 tahun. Perencanaan jangka menengah ini bersifat umum, namun sasaran sudah ditampilkan secara kuantitatif. Contoh: propeda. 3) Perencanaan jangka pendek (short term planning) yaitu jangka waktu 
kurang dari satu tahun hingga mencapai satu tahun. Biasa disebut dengan perencanaan oprasional tahunan, contoh: proyek-proyek.

Perencanaan dari dimensi tingkatan teknis perencanaan. 1) Perencanaan makro yaitu tentang ekonomi dan nonekonomi secara internal maupun eksternal. Perencanaan makro berguna untuk melihat keseimbangan atar dua faktor yaitu faktor internal dan eksternal. Contoh: perencanaan pendidikan nasional. 2) Perencanaan mikro yaitu Perencanaan yang disusun dan dibuat dengan kesesuaian kondisi otonomi daerah pendidikan, biasa disebut dengan pemetaan pendidikan. Perencanaan mikro berguna untuk mengetahui keadaan secara lengkap dan untuk menata kembali jaringan pendidikan agar lebih baik lagi. Sehingga dapat bermanfaat seefesien dan seefektif mungkin. 3) Perencanaan Sektoral yaitu Suatu kumpulan perecanaan yang memiliki ciri dan tujuan yang sama. Guna perencanaan sektoral adalah untuk pembangunan sektor, dalam pembahasan ini adalah sektor pendidikan. Misal: perencanaan pendidikan lokal 4) Perencanaan Kawasan. Perencanaan ini lebih memperhatikan suatu kawasan tertentu sebagai pusat kegiatandengan keunggulan- keunggulan yang komperatif dan kompetitif. Pada perencanaan kawasan terpenting adalah hubungan atau interaksi antardaerah. Misal: perencanaan pendidikan kawasan Indonesia Timur. 5) Perencanaan Proyek yaitu Perencanaan yang disusun untuk membangun dan menuju sasaran tertentu. Perencanaan proyek adalah perencanaan yang bisa menjawab (siapa, apa, bilamana, dimana dan bagaimana) bila melakukan hal tersebut.

Perencanaan dari dimensi jenis (Usman, 2006: 55-56) antara lain: 1) Perencanaan Dari Atas ke Bawah (Top Down Planning); Perencanaan ini disusun oleh ketua atau pemimpin dalam struktur organisasi. 2) Perencanaan Dari Bawah ke Atas (Bottom-Up Planning); Perencanaan yang disusun oleh tenaga perencanaan ditingkat bawah dari suatu struktur lalu disampaikan ke ketua organisasi. Misal pada dunia pendidikan. Guru merencanakan suatu kegiatan lalu disampaikan pada kepala sekolah lalu kepalasekolah menyampaikan pada kepala dinas. 3) Perencanaan 
Menyerong ke Samping (Diagonal Planning); Perencaan yang disusun oleh pejabat dengan pejabat lainnya yang berada ditingkatan bawah di luar organisasi. 4) Perencanaan Mendatar (Horizontal Planning); Perencanaan yang biasanya dibuat atau disusun oleh pejabat selevel lintas sektoral. 5) Perencanaan Menggelinding (Rolling Planning); Perencanaan ini biasa disusun oleh pejabat yang memiliki wewenang dalam perencanaan bentuk jangka pendek, jangka menengah maupun jangka panjang.

\section{Desain Pembelajaran}

Dalam pembelajaran, desain juga sangat penting dan harus diperhatikan, dibawah ini adalah sepuluh unsur yang harus memperoleh perhatian sebelum melaksanakan kegiatan pembelajaran: 1) Perkiraan suatu kebutuhan, guna mengatur suatu tindakan pada program pengajaran. 2) Pemilihan pokok pelajaran atau pembahasan dan tugastugas untuk dilaksanakan. Serta menunjukan tujuan umum yang akan dicapai. 3) Mengetahui ciri siswa, untuk mengetahui tindakan apa yang harus di dilakukan dan diperhatikan selama perencanaan. 4) Menentukan isi pelajaran dan unsur tugas sesuai dengan apa yang ingin dituju. 5) Adanya tujuan belajar yang akan dicapai dengan isi pelajaran dan unsur tugas yang sudah dirancang. 6) Desain kegiatan pembelajaran (belajarmengajar) guna mencai tujuan yang sudah ditetapkan. 7) Memilih media pendukung. 8) Adanya layanan penunjang untuk melaksanakan dan mengembangkan kegiatan pembelajaran. 9) Desain dan persiapan evaluasi hasil kegiatan pembelajaran dan hasil pogram. 10) Uji awal pada pelajar untuk menentukan pelajaran dan tindakan yang sesuai (Kemp, 1994: 1314).

Keberadaan unsur-unsur tersebut merupakan hal yang sangat penting dalam proses dalam menyusun bahan ajar, metode, pendekatan, media, dan penilaian dalam kurun waktu tertentu guna mencapai target yang diinginkan (Ernawati, Arabiyat, 5 (1), 2018: 15-37).

\section{Model dan Srategi Pembelajaran Kalam Inovatif}

Model Pembelajaran Kalam Inovatif antara lain: a) Tanya jawab. Diawali dengan pengajar bertanya pada pelajar satu, lalu berkelanjutan 
siswa satu bertanya pada siswa lain dan seterusnya. b) Menghafal model dialog. Pengajar memberi contoh lalu dihafal dan ditirukan oleh pelajar dengan mimik, gerak dan ekspresi sesuai teks dialog. c) Percakapan terpemimpin. Pengajar memberi konteks atau topik, lalu pelajar mengembangkan imajinasinya dan berbicara dengan lawan bicara sesuai topik. d) Percakapan Bebas. Pengajar memberi topik, kemudian pelajar bebas berbicara sesuai topik (Mustofa, 2007 : 138-141).

Strategi Pembelajaran Kalam Inovatif, antara lain: a) Strategi langsung. Strategi ini bertujuan untuk melatih menceritakan apa yang di lihat dalam bahasa Arab dengan lisan maupun tulisan. b) Strategi jigsaw. Strategi untuk memahami bacaan dan diulang berkali-kali. c) Strategi grup kecil. Pada strategi ini pengajar membagi dan memberi tugas pada kelompok kecil. Kemudian mereka mempresentasikannya yang bertujuan untuk mengaktifkan pelajar. d) Strategi lihat gambar. Pelajar diharap membaca teks dan menuangkannya pada gambar, yang bertujuan untuk mempermudah pelajar mengingat teks tersebut.

\section{Perencanaan Pembelajaran di Lembaga Kursus Bahasa Arab Al-Azhar}

Berdasarkan wawancara, observasi dan dokumentasi dapat peneliti paparkan bahwa di Al-Azhar Pare memasarkan beberapa program dengan perencanaan pembelajaran yang berbeda-beda. Program-program tersebut diantaranya; Tamyiz, Full Time 1, Full Time 2, Full Time 3 dan Qowaid alManhaji.

\section{Perencanaan dari Dimensi Waktu}

Pada setiap program yang dipasarkan waktu yang ditentukan berbeda-beda tetapi tetap tergolong dimensi waktu jangka pendek. Program ini bila dibagi berdasarkan waktunya terbagi menjadi tiga bagian, program dua minggu, satu bulan dan Liburan. Pembagiannya sebagai berikut: 1) Program dua minggu hanya satu kelas yakni Pre Full Time 1 plus asrama. 2) Program satu bulan, terdapat empat kelas yakni Tamyiz 1\&2 Tamyiz 3\&4, Full Time 1, Full Time 2, Full Time 3 dan Qowaid alManhaji. 3) Untuk program Liburan terdapat beberapa opsi, satu minggu, 
dua minggu dan tiga minggu. 4) Spesial ramadhan mempunyai dua opsi yakni dua minggu dan satu bulan (Full Time 1\&2 dan Qowaid al-Manhaji).

\section{Perancanaan dari Dimensi Tingkatan Teknik Perencanaan}

Perencanaan pembelajaran yang didasarkan pada tingkatan teknik perencanaan di Al-Azhar pada setiap program berbeda disesuaikan kebutuhan dan kemampuan peserta didik. Kegiatan belajar mengajar dipimpin oleh pengajar yang telah dijadwalkan dan waktu yang telah ditentukan serta metode pembelajaran yang digunakan menyesuaikan pelajaran yang disampaikan. Hari aktif di Al-Azhar ada 5 hari dalam satu minggu; Senin-Jum'at. yang bertempat di asrama Al-Azhar dan program.

Pada program Tamyiz peserta didik mendapatkan satu kali pertemuan untuk pemanasan (hafalan mufrodat dengan lagu), satu kali pertemuan penyampaian materi, dua kali pertemuan praktek. Setiap pertemuannya terhitung 90 menit, pembelajaran menggunakan lagu untuk memudahkan peserta didik menghafal mufrodat. Pada program ini ditekankan pada Qawaid Dasar dan terjemah Al-Qur'an. Sedangkan penilaian dan evaluasi belajar melalui tiga hal; ujian harian, ujian mingguan dan ujian akhir.

Pada program Full Time 1 peserta didik mendapatkan tiga kali pertemuan muhadasah, satu kali pertemuan qawaid lilmuhadasah, satu kali pertemuan mufrodat dan satu kali pertemuan study club pada setiap pertemuannya terhitung 90 menit. Target pada program ini ialah mampu berbicara bahasa Arab dari dasar, mahir muhadasah, menghafal 2000 mufrodat. Diwajibkan 24 jam berbahasa Arab. Evaluasi dan penilaian melalui tiga hal; ujian harian, ujian mingguan dan ujian akhir. Program ini dimulai pada periode tanggal 10 atau biasa mereka sebut dengan periode 10.

Pada program Full Time 2 peserta didik mendapatkan tiga kali pertemuan muhadasah, satu kali pertemuan mufrodat, satu kali pertemuan qawaid dan satu kali study club. Pada program ini ditekankan untuk mahir muhadasah tingkat lanjut. Diadakannya placement test untuk mengikuti program ini apabila tidak lolos wajib untuk mengambil 
program muhadasah dasar terlebih dahulu. Peserta didik juga ditargetkan menghafal 2000 mufrodat termasuk sinonim dan antonim. Diwajibkan 24 jam berbahasa Arab. Evaluasi dan penilaian yang digunakan; ujian harian, ujian mingguan dan ujian akhir. Program ini dimulai hanya pada periode 10.

Pada program Full Time 3 peserta didik akan mendapatkan tiga kali pertemuan qawaid, satu kali pertemuan adad ma'dud, satu kali pertemuan study club. Penekanan pada program ini ialah lancar membaca kitab kuning serta mampu membaca kitab apapun dengan baik dan benar. Diadakan placement test untuk program ini apabila tidak lolos wajib untuk mengambil program muhadasah terlebih dahulu. Diwajibkan 24 jam berbahasa Arab. Penilaian dan evaluasi yang digunakan; ujian harian, ujian mingguan dan ujian akhir. Program ini dimulai tiap periode 10.

Pada program Qowaid al-Manhaji peserta didik mendapatkan tujuh kali pertemuan dalam satu hari. Penekanan pada program ini mengulas seluruh rahasia Nahwu dan Sharaf pada tiga kunci dan dua puluh rumus yang dapat digunakan untuk membaca kitab kuning baik dari segi makna, i'rob, kedudukan kalimat. Diwajibkan 24 jam berbahasa Arab.

Program liburan materi yang disampaikan hampir sama dengan program yang satu minggu, dua minggu, tiga minggu. Materinya menyesuaikan kesepakatan apakah muhadasah atau qawaid yang diajarkan. Pada program ini diwajikan juga 24 jam menggunakan bahasa Arab dengan kapasitas tiap program yang lebih kecil dari program umum hanya lima belas orang.

\section{Perencanaan dari Dimensi Jenis}

Struktur kepengurusan di Al-Azhar dapat kami paparkan sebagai berikut;

$\begin{array}{ll}\text { Pendiri/ Direktur } & \text { : Ustadz Muslikhin dan Ustadz } \\ & \text { Rohmanudin } \\ \text { Bagian Kurikulum } & \text { : Ustadz Mansur } \\ \text { Bagian Marketing } & \text { : Ustadz Mughni } \\ \text { Bagian Administrasi } & \text { : Ustadz Anas }\end{array}$


Pada hasil wawancara kami dengan narasumber beliau tidak memberikan pembagian yang jelas hanya berupa desripsi, kurang lebih peneliti dapat memberikan gambaran struktur sebagai berikut:

Gambar struktur lembaga kursus Bahasa Arab al-Azhar Pare, Kediri

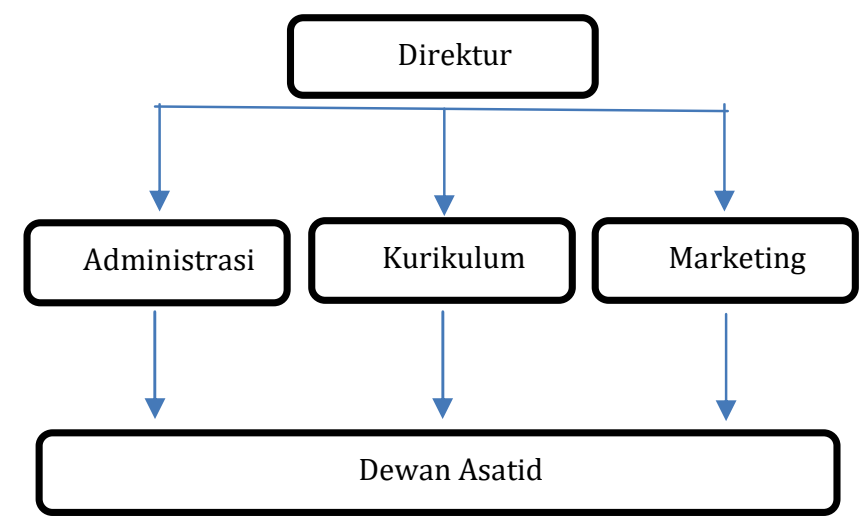

Al-Azhar merupakan lembaga kursus bahasa Arab yang terkenal dan menjadi salah satu lembaga kursus yang favorit di pare. Al-Azhar memiliki program-program yang menarik bagi pembelajar bahasa Arab khususnya, umumnya bagi pembelajar bahasa Asing di Pare Kediri. Program-program yang dimiliki oleh Al-Azhar meliputi program 2 mingguan yang berupa Pre-Full Time 1 plus asrama. Kemudian Tamyiz 1, 2, 3, \& 4. Full Time 1, 2, \& 3, dan Qowaid al-Manhaji yang mana program tersebut berdurasi selama 1 bulan. Adapun untuk program liburan terdapat pilihan, mulai dari 1, 2 hingga 3 minggu. Sedangkan khusus program Spesial Ramadhan mempunyai dua opsi yakni 2 minggu dan 1 bulan (Full Time 1\&2 dan Qowaid al-Manhaji). Karena program ini tidak sampai 1 tahun, maka termasuk pada perencanaan dimensi waktu jangka pendek (Usman, 2006: 48).

Dari segi perencanaan dimensi tingkatan teknis al-azhar termasuk pada jenis perencanaan proyek. Karena perencanaan al-azhar dalam pembelajaran sesuai dengan kebutuhan dan tujuan siswa yaitu mampu berbicara bahasa Arab aktif. Misal pemberian mufrodat di muhadasah yang bertujuan untuk memudahkan pelajar berbicara bahasa Arab, karena pelajar memiliki banyak kosakata. Berbicara bahasa Arab selama 24 jam 
yang bertujuan untuk mengasah kemampuan dan kelancaran berbicara bahasa Arab serta untuk mengingat mufrodat yang sudah diberikan. Hal tersebut menunjukkan bahwasannya perencanaan yang disusun oleh lembaga Al-Azhar adalah untuk membangun dan menuju sasaran tertentu yaitu berbicara bahasa Arab aktif (Usman, 2006 : 48). Lembaga kursus AlAzhar termasuk perencanaan jenis top-down planing karena pada lembaga ini dipimpin oleh pendiri. Perencanaan pembelajaran dirancang dan disusun oleh direktur kemudian dilaksanakan oleh anggota-anggotanya (Usman, $2006:$ 48).

\section{Desain Pembelajaran di Lembaga Kursus Bahasa Arab Al-Azhar}

Kaitannya dengan pembelajaran Bahasa Arab di Lembaga Kursus Bahasa Arab Al-Azhar terdapat beberapa bentuk desain sebagaimana berikut:

\section{Tindakan Pengajaran Sesuai Kebutuhan}

Kebutuhan peserta didik belajar bahasa Arab di Al-Azhar runtuk meningkatkan kemampuan berbahasa Arab. Kebutuhan berbahasa yang dicari peserta didik pada umumnya ialah mampu menggunakan bahasa Arab dengan aktif dan pasif, dapat berkomunikasi menggunakan bahasa Arab serta dapat memahami teks bahasa Arab. Berdasarkan kebutuhan ini Al-Azhar membagi dua kelas umum, kelas kalam untuk memenuhi kebutuhan berbicara/berkomunikasi bahasa Arab dan kelas gramatika untuk memenuhi kebutuhan mampu membaca bahasa Arab dengan kaidah yang benar.

\section{Pemilihan Pokok Pelajaran dan Tugas-tugas untuk Dilaksanakan}

Pokok pelajaran yang terdapat di Al-Azhar berupa muhadasah dan qawaid. Muhadasah diajarkan di program Full Time 1, 2 dan 3. Qawaid diajarkan di program Qowaid al-Manhaji materi yang diajarkan rahasia Nahwu dan Sharaf. Sedangkan program Tamyiz diajarkan untuk membaca kitab kuning dan terjemah al-Qur'an serta Qawaid dan menekankan pada al-Qur'an. 
Tugas-tugas yang harus dilaksanakan ketika kegiatan belajar mengajar bagi pengajar menyiapkan materi, media serta memilih metode yang akan digunakan. Untuk program Full Time media yang digunakan mp3 dan metode yang digunakan metode langsung. Untuk program qawaid metode yang digunakan al-manhaji dan melakukan drill mufrodat setiap pagi.

\section{Mengetahui Ciri Siswa}

Ciri siswa aktif di kelas, yang perlu dilakukan oleh guru ketika di kelas memberikan kesempatan peserta didik untuk mengolah informasi yang mereka dapatkan, semisal setelah diberi materi diberikan kesempatan untuk berbicara di depan mengguankan bahasa Arab. Cara yang lain juga bisa digunakan melatih siswa untuk menajamkan daya analisa peserta didik seperti memberikan soal tentang gramatika kemudian peserta didik dipersilakan untuk menganalisa i'rob dan kedudukan kalimat.

\section{Menentukan Isi Pelajaran dan Unsur Tugas}

Penentuan Isi Pelajaran Pada Program Full Time Meliputi; AlMufrodat, Al-'Ibarat, al-muhadasah, al-lu'bah, al-musabaqah, al-taqdim, alghina', al-khitobah, al-qawaid dan al-'adad. Untuk program Qowaid alManhaji rahasia Nahwu dan Sharaf yang ternyata rahasianya terdapat pada tiga kunci dan dua puluh rumus berupa i'rob, kedudukan kalimat, bina', shigat kalimat dan perubahan kalimat. Sedangkan program Tamyis menekankan pada terjemah al-Qur'an, qawaid dasar dan praktek membaca kitab kuning.

\section{Adanya Tujuan Belajar Yang Akan Dicapai Dengan Isi Pelajaran dan Unsur Tugas yang Sudah Dirancang}

Setiap program mempunyai tujuan pembelajaran yang berbeda, dapat disimpulkan seperti berikut: 1) Tamyiz 1\&2; menguasai kaidahkaidah nahwu dan sharaf, mampu membaca kitab kuning dan tajamah alQur'an dasar dengan mudah dan menyenangkan. 2) Tamyiz 3\&4; mampu menganalisa secara teoritis nahwu dan sharaf, mampu memahami alQur'an dan kitab kuning dengan baik dan benar. 3) Full Time 1; mampu 
menghafal 2000 mufrodat berkenaan dengan materi yang diajarkan. 4)

Full Time 2; mampu menghafal 2000 mufrodat lebih mendalam dan detail. 5) Full Time 3; mampu menghafal 2000 mufrodat ilmiah. 6) Qowaid alManhaji; mampu membaca dan memahami kitab kuning dengan baik dari segi i'rob, kedudukan kalimat.

\section{Desain Kegiatan Pembelajaran Lembaga Kursus Bahasa Arab Al-Azhar}

Di Al-Azhar Pare tidak membuat desain kegiatan pembelajaran karena tidak mengacu pada kurikulum lembaga pendidikan formal sehingga tidak terdapat standar kompetensi dan kompetensi dasar.

Media yang digunakan hanya ada pada program Full Time dengan menggunakan Mp3 sedangkan kelas yang lain tidak menggunakan media. Adapun layanan penunjang di Al-Azhar yaitu: 1) Asrama. Dengan adanya asrama ini lebih efektif untuk membentuk lingkungan berbahasa Arab. Dan memberikan peserta didik pelayanan tempat tinggal dan makan yang harganya lebih terjangkau. 2) Ruangan Kelas. Kelas yang disediakan di AlAzharbersih dan rapi, meskipun beberapa kelas masih menggunakan ruangan asrama dan teras asrama sebagai kelas.

Evaluasi yang digunakan untuk memperoleh hasil dari rangkaian pembelaran melalui tiga hal; ujian harian, ujian mingguan dan ujian akhir. Yang mana semuanya dipimpin oleh pengajar. Di Al-Azhar diperkenankan pada peserta didik untuk memilih paket yang dipasarkan, akan tetapi tetap diadakan placement test untuk mengetahui kemampuan peserta didik agar tidak salah masuk program. Karena program yang diajarkan di AlAzharmempunyai tingkatan seperti program Full Time 1,2\&3 apa bila ingin mengambil program 2 atau program 3 tetapi tidak lolos maka wajib mengikuti program satu tingkat dibawahnya.

Dalam desain pembelajaran ada unsur-unsur yang harus dipenuhi sebelum pembelajaran dilaksanakan. Seperti bahan ajar, metode, media dan evaluasi. Desain pembelajaran yang disusun oleh Al-Azhar berdasarkan dari kebutuhan siswa, yaitu siswa mampu berbahasa Arab aktif. Pertama diadakan placement test guna mengetahui tingkat kemampuan siswa 
sebelum memasuki kelas. Adapun kelas di Al-Azhar dibagi menjadi dua, yakni kelas kalam dan kelas gramatika, yang mana materi dan tugas-tugas disesuaikan dengan kebutuhan siswa. Kemudian ada kekurangan dalam media pembelajaran dan layanan penunjang. Al-Azhar hanya menggunakan media berupa mp3, dan hanya dipergunakan di kelas Full Time. Kemudian layanan penunjang pembelajaran di Al-Azhar terbatas, ruangan kelas yang disediakan adalah rumah yang dialihfungsikan menjadi kelas, seperti teras, ruang tengah. Meskipun ada sebagian ruangan yang dikhususkan fungsinya sebagai kelas. Dalam hal ini lembaga Al-Azhar sangat memperhatikan unsurunsur seperti kebutuhan, materi, layanan penunjang, dan evaluasi harus diperhatikan sebelum melaksanakan kegiatan pembelajaran (Kemp, 1994: 13-14).

Dalam pembelajaran, Al-Azhar memiliki model pembelajaran yang variatif dan menarik. Pada kelas Tamyiz model pembelajaran yang digunakan adalah model pembelajaran terpimpin, guru memberikan mufrodat untuk dihafal kemudian disetorkan kepada guru di pertemuan selanjutnya. Sedangkan model pembelajaran di kelas Full Time menggunakan model percakapan terpimpin dan bebas, siswa diberikan topik tertentu kemudian siswa mempraktekannya di depan kelas dan bercakap-cakap dengan temannya. Oleh karena itu pembelajaran di Al-Azhar menggunakan model yang variatif dan model pembelajaran kalam inovatif yang terdiri dari model pembelajaran kalam tanya jawab, menghafal dialog, percakapan terpemimpin dan percakapan bebas (Mustofa, 2007: 138-141).

Adapun strategi pembelajaran yang digunakan Al-Azhar dalam pembelajaran di kelas Tamyiz adalah strategi jigsaw, dimana tujuan pembelajaran pada kelas ini memperkaya kosakata Arab (mufrodat) dengan cara mengulang-ulang kata yang dipelajari supaya cepat dihafalkan (Mustofa, 2007: 138-141). Kelas Full Time juga menggunakan strategi jigsaw, akan tetapi kosakata yang dihafalkan lebih banyak, dan disertai dengan materi kaidah bahasa Arab agar pada kelas Full Time 3 yang mana tujuan pembelajarannya adalah memahami kitab kuning, maka dengan hal tersebut 
siswa dapat dengan mudah memahaminya karena sudah memiliki kosakata yang banyak dan kaidah yang mumpuni.

\section{Kesimpulan}

Hasil tulisan ini menginformasikan mengenai beberapa hal antara lain; 1) Lembaga kursus bahasa Arab Al-azhar menggunakan perencanaan jangka pendek karena terdiri dari program mingguan dan bulanan. Manajemen perencanaan yang ada pada lembaga kursus Al-Azhar termasuk perencanaan proyek. Perencanaan disusun guna mewujudkan tujuan siswa yaitu pandai berbicara bahasa Arab. Perencanaan top-down menjadi kategori lembaga kursus Al-Azhar, karena program-program yang disediakan dibuat oleh direktur kemudian dilaksanakan oleh anggota-anggotanya. 2) Adapun desain pembelajaran di lembaga Al-Azhar berdasarkan pada kebutuhan siswa guna mengatur suatu tindakan pengajaran. Kemudian pemilihan pokok pembelajaran disesuaikan dengan tujuan yang akan dicapai siswa. Dan evaluasi merupakan akhir dari desain pembelajaran selama periode tertentu. Model dan strategi pembelajaran yang digunakan oleh Al-Azhar sangat variatif, dari model percakapan terpimpin, percakapan bebas. Adapun strategi pembelajaran kalam yang digunakan adalah strategi langsung dan strategi Jigsaw yang berpusat pada tujuan utama yaitu berbicara kalam aktif.

\section{Daftar Rujukan}

Ainin, Moh. Metodologi Penelitian Bahasa Arab. Malang: CV. Bintang Sejahtera, 2016.

Arifin, Zainal. Evaluasi Pembelajaran, Prinsip, Teknik, Prosedur. Bandung: PT. Remaja Rosdakarya, 2009.

Arikunto, Suharsimi. Pengelolaan Kelas dan Siswa Sebuah Pendekatan Evaluatif. Jakarta : PT. Raja Grafindo Persada, 1996.

Arikunto, Suharsimi. Prosedur Penelitian suatu pendekatan praktik. Jakarta: penerbit Rineka Cipta, 2010.

Emzir. Metodologi Penelitian Pendidikan Kuantitatif dan Kualitatif. ed.Revisi, Depok: PT. Rajagrasindo Persada, 2017. 
Ernawati, Euis. Perencanaan Pembelajaran Bahasa Arab di Perguruan Tinggi Pariwisata, (Sekolah Tinggi Agama Islam Syeikh Mansyur Banten Indonesia), Arabiyat, Vol. 5 No. 1, Juni 2018, 15-37.

Fatah, Nanang. Landasan Manajemen Pendidikan. Bandung: Remaja Rosdakarya, 2001.

Harsono. Pengelolaan Perguruan Tinggi. Yogyakarta: Pustaka Pelajar, 2016.

Kemp, Jerrold E. Proses Pedesain Pengajaran. terjemahan: Asril Marjohan. Bandung: Penerbit ITB, 1994.

Mustofa, Syaiful. Strategi Pembelajaran Bahasa Arab Inovatif. Malang: UIN Maliki Press, 2007.

Meier, Dave. The Accelerated Learning. ed.Terjemahan. Bandung: Kaifa, 2002.

Meleong, Lexy J. Metode Penelitian Kualitatif. Bandung: PT. Remaja Rosydakarya, 2014.

Miles, M.B, Huberman, A.M, dan Saldana, J. Qualitative Data Analysis, A Methods Sourcebook, Edition USA: Sage Publications. Terjemahan Tjetjep Rohindi Rohidi. Jakarta: UI-Press, 2014.

Pidarta, Made. Manajemen Pendidikan Indonesia. Jakarta: PT. Rineka Cipta, 2003.

Rahmawati, Alvi Dyah. Manajemen Pengorganisasian Program Kursus Bahasa Arab di Pare Kediri, (UIN Maulana Malik Ibrahim Malang), Journal of Arabic Studies, 3 (1), 2018, 52-60..

Rohman, Muhammad dan Sofan Amri. Manajemen Pendidikan: Analisis dan Solusi terhadap Kinerja Manajemen Kelas dan Strategi Pengajaran yang Efetif. Jakarta: PT. Prestasi Pusta Karya, 2015.

Soejono dan Abdurrahman. Metode Penelitian Suatu pemikiran dan Penerapan. Jakarta: PT Rineka Cipta, 1999.

Sudjana, Nana. Manajemen Program Pendidikan Untuk Pendidikan Luar Sekolah Dan Pengembangan Sumber Daya Manusia. Bandung: Falah Production, 2000.

Sudjana, Nana. Dasar-Dasar Proses Belajar Mengajar. Bandung: PT. Sinar Baru Algensindo, 2000. 
Sulistyo, Basuki. Metode Penelitian. Jakarta: Wedatama Widya Sastra, 1999.

Suryapermana, Nana. Manajemen Perencanaan Pembelajaran, (UIN Sultan Maulana Hasanuddin Banten), Tarbawi: Jurnal Keilmuan Manajemen Pendidikan, Vol. 3 No. 02, November 2017.

Suryobroto. Manajemen Pendidikan di Sekolah. Jakarta: PT. Rinneka Cipta, 2006.

Talibo, Ishak Wanto. Fungsi Manajemen dalam Perencanaan Pembelajaran, (IAIN Manado), Jurnal Ilmiah Iqra', Vol. 7, No. 1, 2013.

Usman, Husain Manajemen Teori, Praktik, dan Riset Pendidikan. Jakarta: PT. Bumi Aksara, 2006. 